\title{
Development of Manakarra Value Integrative Model in Learning Introduction to Education Course
}

\author{
Yusran $^{1}$, Syamsul Bachri Talib ${ }^{2}$, Hamsu Abdul Gani ${ }^{3}$ \\ ${ }^{1}$ Department of Educational Science, Universitas Negeri Makassar \\ Jln. Bonto Langkasa Kampus Gunung Sari Baru, Makassar, South Sulawesi, Indonesia \\ Email: yoesbone [AT] gmail.com
}

${ }^{2}$ Department of Psychology, Universitas Negeri Makassar Jln. Mapala Raya No. 1, Makassar, South Sulawesi, Indonesia Email: syamsult [AT] yahoo.com

\author{
${ }^{3}$ Department of Engineering, Universitas Negeri Makassar \\ Jln. Daeng Tata Raya, Makassar, South Sulawesi, Indonesia \\ Email: hamsuabdulgani [AT] yahoo.com
}

\begin{abstract}
This study aims to produce a valid, practical, and effective Manakarra value integrative model learning tool that students can implement in the Introduction to Education course. The development of learning tools using the 4-D model and tested on students of the Faculty of Teacher Training and Education, Tomakaka University, Study Program of Indonesian Language and Literature Education. The research design used One-Group Pretest-Posttest Design. Data collection was using observation, tests, and questionnaires. The data analysis technique used quantitative/qualitative descriptive analysis. Learning the Manakarra value integrative model begins with the validity of learning tools; Model Books, Teaching Materials, Semester Learning Plans (RPS), Student Activity Sheets and Learning Outcomes Test Instruments. Furthermore, a trial was conducted on students in learning the Introduction to Education course. The implementation of the learning stages seen in student learning activities showed a very good improvement and enthusiasm in carrying out learning. Students can follow the learning process by using learning tools developed with high curiosity. The effectiveness of the Manakarra value integrative model from the trial results shows that the integrative model's learning process has succeeded in improving students' critical thinking skills.
\end{abstract}

Keywords--- Integrative Learning, Learning Outcomes, Critical Thinking Skills.

\section{INTRODUCTION}

The recent information era on the cultural frame is closely related to the mindset of life. One of the cultural products of our ancestors and has received legitimacy from the community for a long time and has become a guideline and a way of life for the people of Indonesia. Some events caused by modernization with various kinds of negative phenomena nowadays can eliminate the culture's values. One of the most important causes is the education value where globalization has a major influence on changes in society and its environment simultaneously with the rate of world development. Thus, there are also changes in mindset and dynamics in society.

In the context of Mandar culture, according to (Idham \& Shaprillah, 2013), education helps humans from the status of tau-tau (people is only a human form) becomes tau tong'an (humans with human traits). Therefore, education for a person is to instil a pattern of understanding attitudes and behaviour as a guide in life, as the expression of Puang di Posang's ( $I$ Pasu Tajibarani) emphasized in front of Tomepayung that the main criteria for a Mandar namely: itaq to Mandar ceraq mappamula, sipaq mappamixang disesena tau pia tonganan (we are Mandar people, the blood criteria are only at the beginning, and the nature of Allah that determines in the end for those who have virtue, amala biang) (Idham \& Shaprillah, 2013).

The existence of Introduction to Education course in higher education is very important to be implemented. The material presented is related to human life, both within the family, community, and nation and state. With a good education quality, then the community will get a decent life. Thus, it becomes a process that is considered to realize the aspirations of the people. However, education should be with the culture to realize the knowledge and understanding of the history of the younger generation in the future. Based on this description, realizing local culture-based learning requires understanding, 
understanding, awareness, cooperation, and participation of all elements, including family, environment, schools/colleges, managers of educational institutions, and even the government.

Based on the description of the background, the researcher has some things to explore. The first is the description of the need in using the integrative learning model. The second is the the integrative learning model design. The third is the validity and practicality of the integrative learning model. The fourth is the effectiveness of the Manakarra value integrative learning model towards improving character and learning outcomes.

\section{LITERATURE REVIEW}

\subsection{Learning Concepts of Introduction to Education}

The existence of Introduction to Education courses in higher education is very important to be implemented. The material presented is very related to human life, both within the family, community, and nation and state. With a good quality education, people will get a decent life. Thus, it becomes a process that is considered capable of realizing the aspirations of the community. However, education must always go hand in hand with culture in order to realize the knowledge and understanding of the history of the younger generation in the future. Cultural development in the scope of education that is continuously carried out can support the sustainability of cultural life, which has influence and character, identity, and integrity for the Indonesian people, especially for students. This factor affects the strength or resilience of local culture against cultural influences from within and from outside or caused by internal and external factors. According to Sedyawati, cultural resilience is defined as the ability of a culture to maintain its identity, not by rejecting all foreign elements, but by filtering, selecting, and if necessary, modifying external cultural elements in such a way that it remains following the character and image of the nation (Sedyawati, 2012).

\subsection{Constructivism Learning Model}

Constructivism as a learning theory has implications for learning theory. Constructivism learning theory comes from the school of philosophy of knowledge which emphasizes that knowledge is a construction of itself. Construction means constructive, in the context of constructivism's educational philosophy, is an effort to build knowledge with a modern culture, one of which is by improving the education system. However, you must first know how humans learn and how to teach them. Both of these activities are in order to understand how humans construct knowledge about objects and events encountered during their lives. Humans will look for and use things or tools that can help understand their experiences.

According to (Aqib, 2014), the view of constructivism learning theory is an effort to build understanding or perception on the basis of experiences experienced by students. Thus learning according to this theoretical view is a process to provide authentic experiences for students. There are three potentials that

must be changed through learning, namely intellectual potential (cognitive), moral personality potential (affective) and mechanical/muscle skills (psychomotor). Meanwhile, according to (Budiningsih, 2005), learning is a process of knowledge formation. Students must carry out this formation to interpret information into their minds, only in the context of their own experience and knowledge, on their needs, backgrounds and interests. In addition, he must actively carry out activities, actively think, formulate concepts and give meaning to the things being studied. Meanwhile, educators organise an environment that can provide optimal opportunities in the learning process to help students construct an understanding of the representation of the conceptual function of the external world.

In constructivism learning, educators and students play a role in helping the process of knowledge construction by students run smoothly. Educators do not transfer the knowledge they already have but help students to form their knowledge. Educators are required to understand better the way of thinking or the perspective of students in learning. Educators cannot claim that the only way is the same and according to his will.

The constructivism approach emphasizes that the main role in learning activities is the activity of students in constructing their own knowledge. Everything such as materials, media, equipment, environment, and other facilities are provided to help the formation. Students are given the freedom to express their opinions and thoughts about something they face. In this way, students will be accustomed and trained to think for themselves, solve the problems they face, be independent, critical, creative, and account for their thinking rationally.

In line with the explanation above, (Kondziolka et al., 1992) suggests three emphases in constructivism learning theory as follows. The first is the active role of students in constructing knowledge meaningfully. The second is the importance of making meaningful connections between ideas in construction. The third is linking ideas with new information received.

(Gray \& Wheatley, 1991) supports the above opinion by proposing two main principles in learning with constructivism learning theory. First, knowledge cannot be acquired passively but actively by the cognitive structure of learners. Second, the function of cognition is adaptive and helps organize through real experiences that children have. The two definitions above emphasize the importance of the active involvement of children in the process of linking several ideas and 
constructing knowledge through their environment. In fact, specifically, (Hudoyo, 1990) says that a person will be easier to learn something if learning is based on what other people already know.

In an effort to implement constructivism learning theory, (Abbot et al., 2005) put forward several suggestions related to learning design, as follows: (1) providing opportunities for students to express their ideas in their own language, (2) providing opportunities for students to think about their experiences so that they become more creative and imaginative, (3) provide opportunities for students to try new ideas, (4) provide experiences related to ideas that students already have, (5) encourage students to think about changing their ideas, and (6) create a conducive learning environment.

\subsection{Humanistic Learning Model}

The humanistic theory will greatly assist educators in understanding the direction of learning on a wider dimension so that any learning effort and in any context will always be directed and carried out to achieve its goals. Although this humanistic theory is still difficult to translate into practical and operational learning steps, the contribution of this theory is very large. The ideas, concepts, taxonomies of objectives that have been formulated can help educators and teachers to understand the nature of the human psyche. This will assist them in determining the components of learning such as the formulation of objectives, the determination of materials, the selection of learning strategies, and the development of evaluation tools towards the formation of the aspired human being.

In practice, this humanistic theory tends to direct students to think inductively, emphasizes experience, and requires the active involvement of students in the learning process. (Suciati \& Irawan, 2001) suggests that the steps of learning with a humanistic approach include; (1) Determine learning objectives; (2) Determine learning materials; (3) Identify the initial ability (entry behaviour) of students; (4) Identify lesson topics that allow students to involve themselves or experience in learning actively; (5) Designing learning facilities such as learning environment and media; (6) Guiding students to learn actively; (7) Guiding students to understand the nature of the meaning of their learning experience; (8) Guiding students to conceptualize their learning experience; (9) Guiding students in applying new concepts to real situations; and (10) Evaluating the process of learning outcomes.

\subsection{Manakarra Value Integrative Learning Model}

Manakarra's value integrative learning model is a strategy for creating learning environments and designing learning experiences that integrate culture as part of the learning process. This aims to instil cultural awareness with the character of true identity in preserving the values of local wisdom. Local culture must be a concern and developed based on regional potential.

Therefore, the author will examine the learning model based on local culture as a medium to preserve local cultural values based on an icon from Mamuju Regency, namely Manakarra.

Manakarra is a trust, a lucky inheritance, a powerful heirloom and a guide. All the ideals and meanings contained in the value of Manakarra are the inheritance and bettors of the ancestors who have been handed down since time immemorial, which is the responsibility of future generations to bring this area to a level of prosperity and glory (Thahir, 2006). This concept will later be integrated into the Introductory Education course material at Tomakaka University. Introduction to Education was chosen based on observations and interviews with subject lecturers that the learning system so far is still conventional and lecturer-centred. Thus, it has an impact on the interest and participation of students in following the lecture material. Therefore, through this research, it is hoped that innovations and different learning models can emerge to increase student interest, motivation and learning outcomes. The novelty that occurred in the learning later was Manakarra's values which consisted of: (1) Mapia Ateka' (faithful and pious), (2) Maka (intelligent and skilled), (3) Matona' (polite and modest), (4 ) Madoro Tanni Bassi' (honest and trustworthy), (5) Mataratte' (behave in an orderly manner), (6) Matutu (careful), and (7) Matang Base'Base' (sincerely serving). This value will be integrated into the Introduction to Education course material.

\section{RESEARCH METHODS}

This type of study is Research and Development. Research and development are research-oriented to the development of a product whose development process is described carefully, and the product obtained is evaluated through trials. While development research, according to (Sugiyono, 2010), is a research method used to produce certain products and test the validity, practicality and effectiveness of these products. Research on the Integrative Model of Manakarra Values in Learning Introductory Education Courses held at Tomakaka University Mamuju J1. Ir. H. Juanda No. 77, Mamunyu District, Mamuju Regency, West Sulawesi Province. The research subjects in this Manakarra Values Integrative model research are students of the Indonesian Language and Literature Education Study Program, Faculty of Teacher Training and Education, Tomakaka University, Mamuju. Respondents in this study were active students in the lecture process in the even semester of the 2020/2021 academic year with 22 students. 


\subsection{Data Source}

The data included in this research and development include:

\section{Need Assessment (Needs Analysis)}

In the development of teaching materials, a need assessment is needed to find out whether teaching materials need to be applied to students or students and whether these teaching materials need to be developed to meet the learning needs of students. This is done at the stage of collecting data and information before planning research. This need assessment is in the form of a list of questions used to conduct open interviews with lecturers of introduction to education courses at Tomakaka University. From the results of this need assessment, the ingredients are used to develop teaching materials by combining ideas from researchers. In addition, it also considers the suitability of the vision carried by the location chosen as the research site.

\section{Validity and Reliability}

Instrument trials are given to subjects who have exactly or almost the same character as the actual research object in this study. The trial was conducted by selecting students from the English education study program who were considered to have equality with students who were the subject of research because of the division of students based on majors or study programs. Validity, according to (Sugiyono, 2010) means that the measuring instrument used to obtain data (measure) is valid. Valid means an instrument that has been tested and can be used to measure the truth that should be measured.

Pretest and Posttest Results

A pretest is a model used to determine the initial ability level of students before the teaching materials that have been developed are applied in learning. The purpose of holding a pretest is to determine students' level of understanding and initial knowledge towards subject matter that is worth studying.

\section{RESEARCH RESULT}

Based on the results of a preliminary study as an initial investigation, data related to the cultivation of character values at Tomakaka University Mamuju have been found, including the following:

\subsection{Learning Concept of Introduction to Education}

1. Before starting the lecture, it was found that some students were not serious in greeting the lecturer and even seemed to be playing games. This shows that the value of the Mapia Ateka character (faith and piety) in students is still relatively lacking, therefore learning activities are needed relating to the planting of Mapia Ateka character values (faith and piety).

2. At the start of the lecture, when the lecturer asked questions, it was found that some students did not want to know and did not even try to find answers to the questions asked. This shows that students have not possessed the value of the Maka character (intelligent and skilled). Therefore, learning activities are needed by teaching the value of the Maka character (smart and skilled).

3. When the lecturer delivered the learning objectives/core and explained the learning material, it was found that some students did not pay attention to the material being delivered and even seemed to be playing around. This shows that students have not owned the character values of Matona' (polite and unpretentious). Therefore a learning method or model is needed that allows the instilling of character values in students.

4. When students present the results of their group discussions, they are still overwhelmed and do not seem to master the material in answering questions posed by other students. This shows that the value of Madoro Tanni Bassi's character (honest and trustworthy) is still not embedded in students, so a learning model is needed to instil the value of Madoro Tanni Bassi's character (honest and trustworthy).

5. During the lecture, students often throw tantrums so that the lecture atmosphere is not conducive. This shows that the value of the Mataratte character (behave in an orderly manner) is not yet owned by students thus, a learning model for teaching the value of the Mataratte character (behave in an orderly manner) is needed.

6. When students give feedback or opinions, they are still concerned with their personal opinions without any thoughts or considerations from other students. This shows that students have not possessed the value of the Matutu character (caution); thus, learning to cultivate the value of the Matutu character (caution) is needed.

7. During group work activities, students tend not to want to work together and are still concerned with their individual nature and do not want to help each other. This shows that the value of the Mature Base 'base' (sincere to serve) has not been firmly planted in students, for that a learning model is needed that can instil the values of 
the Mature Base' base (sincerely serving).

\section{2 Validity test}

Observations from the two observers were carried out with the help of data collection tools/research instruments. There are four main activities observed by observers related to the implementation of learning management, especially the application of the steps of the learning model. The four activities in question are the introduction, main activity, closing and class atmosphere. The results of observations on the implementation of the Manakarra value integrative model with the help of a work table can be presented in the following table:

Table 1. Results of Observation of the Implementation of the Manakarra Value Integrative Model

\begin{tabular}{|c|c|c|c|c|c|c|c|c|c|c|c|}
\hline \multirow{3}{*}{ No } & \multirow{3}{*}{ Observed Aspects } & \multicolumn{9}{|c|}{ Assessment } & \multirow{3}{*}{$\begin{array}{c}\text { Average } \\
\text { SAP } \\
1-3\end{array}$} \\
\hline & & \multicolumn{3}{|c|}{$S A P-1$} & \multicolumn{3}{|c|}{ SAP-2 } & \multicolumn{3}{|c|}{ SAP-3 } & \\
\hline & & $P 1$ & $P 2$ & $R T$ & $P 1$ & $P 2$ & $R T$ & $P 1$ & $P 2$ & $R T$ & \\
\hline$I$ & Introduction & 3.6 & 3.4 & 3.5 & 3.8 & 3.6 & 3.7 & 3.8 & 4 & 3.9 & 3.7 \\
\hline$I I$ & Main Activities & 2.8 & 2.7 & 2.7 & 3.2 & 3.2 & 3.2 & 3.5 & 3.5 & 3.5 & 3.2 \\
\hline$I I I$ & Closing & 3.5 & 3 & 3.2 & 3.5 & 3.5 & 3.5 & 4 & 4 & 4 & 3.6 \\
\hline \multirow[t]{3}{*}{$I V$} & Condition of Class & 3 & 3.6 & 3.6 & 3.6 & 3.6 & 3 & 4 & 4 & 4 & 3.6 \\
\hline & Total & $\begin{array}{c}12 . \\
9\end{array}$ & 12.7 & 13 & 14.1 & 13.9 & 13.4 & 15.3 & 15.5 & 15.4 & 14.3 \\
\hline & Average & 3.2 & 3.1 & 3.2 & 3.5 & 3.4 & 3.3 & 3.8 & 3.8 & 3.8 & 3.5 \\
\hline
\end{tabular}

Based on these results, the implementation of learning management with the steps of the integrative model, then obtained the average data for preliminary activities, namely SAP-1 $=3.5$, SAP-2 $=3.7$, SAP-3 $=3.9$ and the average for preliminary activities based on $\mathrm{SAP}=3.7$. As for the core activities, the average data obtained are $\mathrm{SAP}-1=2.7, \mathrm{SAP}-2=$ $3.2, \mathrm{SAP}-3=3.5$ and the average core activity based on the three SAPs $=3.2$. Meanwhile, for closing activities, the average data obtained are SAP-1 $=3.2$, SAP- $2=3.5$, SAP-3 $=4$ and the average for closing activities based on the three SAPs $=$ 3.6. The average data for class atmosphere SAP-1 $=3.6, \mathrm{SAP}-2=3, \mathrm{SAP}-3=4$ and the average data for class atmosphere based on the three SAPs $=3.6$. In general, the numbers presented as a result of observations from the two observers indicate that the average score given by the two observers on the implementation of learning with the tools developed by the researchers is quite stable. With the acquisition of scores that are in the range of numbers $3.00-4.00$. Based on this, it can be concluded that the implementation or the level of absorption of the devices developed with the integrated model is in a good category.

\subsection{Description of Student Learning Outcomes}

The learning outcomes test given to students is used to measure students' critical thinking skills. The learning outcomes test is given based on indicators of critical thinking skills.

\section{Analysis of Learning Outcomes Test}

This critical thinking ability test is a collection of questions used to measure students' ability to solve questions. The questions given in this study are descriptive tests that aim to measure the extent to which critical thinking skills are seen from students' answers. This test is used to obtain data on students' critical thinking skills. The ability to think critically is not only seen from the right or wrong opinions expressed but can also be seen from the ability of students to present their answers. Here we present data on student learning outcomes in the form of pretest and posttest results.

Table 2. Student Learning Outcomes (Pretest)

\begin{tabular}{cccccc}
\hline No & Students & $\begin{array}{c}\text { Maximum } \\
\text { Score }\end{array}$ & $\begin{array}{c}\text { Achieved } \\
\text { Score }\end{array}$ & Percentage & Category \\
\hline 1 & $A S W$ & 28 & 25 & $89.20 \%$ & Very Good \\
2 & $B I$ & 28 & 21 & $75.00 \%$ & Good \\
3 & $R I$ & 28 & 19 & $67.86 \%$ & Adequate \\
4 & $S E$ & 28 & 22 & $78.57 \%$ & Good \\
5 & $W A$ & 28 & 20 & $71.43 \%$ & Adequate \\
6 & $D L$ & 28 & 19 & $67.86 \%$ & Adequate \\
7 & $J U$ & 28 & 22 & $78.57 \%$ & Good \\
8 & SU & 28 & 24 & $85.71 \%$ & Very Good
\end{tabular}




\begin{tabular}{|c|c|c|c|c|c|}
\hline 9 & $D N$ & 28 & 19 & $67.86 \%$ & Adequate \\
\hline 10 & $F E$ & 28 & 18 & $64.29 \%$ & Adequate \\
\hline 11 & $A G$ & 28 & 22 & $78.57 \%$ & Good \\
\hline 12 & $A Y$ & 28 & 19 & $67.86 \%$ & Adequate \\
\hline 13 & $S A$ & 28 & 22 & $78.57 \%$ & Good \\
\hline 14 & $R R L$ & 28 & 23 & $82.14 \%$ & Good \\
\hline 15 & $R A$ & 28 & 20 & $71.43 \%$ & Adequate \\
\hline 16 & $N U R$ & 28 & 22 & $78.57 \%$ & Good \\
\hline 17 & $K D$ & 28 & 20 & $71.43 \%$ & Adequate \\
\hline 18 & $S R$ & 28 & 19 & $67.86 \%$ & Adequate \\
\hline 19 & $N F$ & 28 & 20 & $71.43 \%$ & Adequate \\
\hline 20 & $N J$ & 28 & 20 & $71.43 \%$ & Adequate \\
\hline 21 & $N A$ & 28 & 23 & $82.14 \%$ & Good \\
\hline 22 & $N D$ & 28 & 23 & $82.14 \%$ & Good \\
\hline \multicolumn{3}{|c|}{ AVERAGE } & 21 & $75.00 \%$ & Good \\
\hline
\end{tabular}

Table 3. Student Learning Outcomes (Posttest)

\begin{tabular}{|c|c|c|c|c|c|}
\hline No & Students & $\begin{array}{c}\text { Maximum } \\
\text { Score }\end{array}$ & $\begin{array}{c}\text { Achieved } \\
\text { Score }\end{array}$ & Percentage & Category \\
\hline 1 & $A S W$ & 28 & 27 & $96.43 \%$ & Very Good \\
\hline 2 & $B I$ & 28 & 24 & $85.71 \%$ & Very Good \\
\hline 3 & $R I$ & 28 & 21 & $75.00 \%$ & Good \\
\hline 4 & $S E$ & 28 & 23 & $82.14 \%$ & Good \\
\hline 5 & $W A$ & 28 & 21 & $75.00 \%$ & Good \\
\hline 6 & $D L$ & 28 & 21 & $75.00 \%$ & Good \\
\hline 7 & $J U$ & 28 & 24 & $85.71 \%$ & Very Good \\
\hline 8 & $U L J$ & 28 & 25 & $89.29 \%$ & Very Good \\
\hline 9 & $D N$ & 28 & 22 & $78.57 \%$ & Good \\
\hline 10 & $F E$ & 28 & 23 & $82.14 \%$ & Good \\
\hline 11 & $A G$ & 28 & 24 & $85.71 \%$ & Very Good \\
\hline 12 & $A Y$ & 28 & 22 & $78.57 \%$ & Good \\
\hline 13 & $S A$ & 28 & 23 & $82.14 \%$ & Good \\
\hline 14 & $R R L$ & 28 & 24 & $85.71 \%$ & Very Good \\
\hline 15 & $R A$ & 28 & 22 & $78.57 \%$ & Good \\
\hline 16 & $N U R$ & 28 & 23 & $82.14 \%$ & Good \\
\hline 17 & $K D$ & 28 & 21 & $75.00 \%$ & Good \\
\hline 18 & $S R$ & 28 & 22 & $78.57 \%$ & Good \\
\hline 19 & $N F$ & 28 & 21 & $75.00 \%$ & Good \\
\hline 20 & $N J$ & 28 & 22 & $78.57 \%$ & Good \\
\hline 21 & $N A$ & 28 & 25 & $89.29 \%$ & Very Good \\
\hline 22 & $N D$ & 28 & 26 & $92.86 \%$ & Very Good \\
\hline \multicolumn{3}{|c|}{ AVERAGE } & 23 & $82.14 \%$ & Good \\
\hline
\end{tabular}

Student learning outcomes obtained in the learning process are measured through the provision of learning outcomes tests to students of the Indonesian Language and Literature Education study program. Student learning outcomes based on the table above, the average data for pretest learning outcomes is $75 \%$, and posttest is $82 \%$. These results indicate that student learning outcomes have increased before and after being given treatment. In the two tests of learning outcomes given, the description of the category of students' critical thinking abilities is in a good category. This shows that students' critical thinking ability of the Indonesian Language and Literature Education study program, especially in the Introduction to Education course, still needs to be improved.

\section{Comparative Analysis of Pretest and Posttest}

Comparative analysis of scores on the pretest and posttest was conducted to determine the progress of student learning outcomes from before using the teaching materials and after using the developed teaching materials. /in testing the comparative analysis of pretest and posttest, using the Paired Samples T-Test on the IBM SPSS statistical version 20 application. Based on the table above, it can be seen that the comparison of student learning outcomes with the average pretest learning outcome of 21 and posttest of 23. These results indicates that student learning outcomes have increased 
before and after being given treatment.

Table 4. Paired Samples Statistics

\begin{tabular}{|c|c|c|c|c|c|}
\hline & & Mean & $N$ & $\begin{array}{c}\text { Std. } \\
\text { Deviation }\end{array}$ & $\begin{array}{c}\text { Std. Error } \\
\text { Mean }\end{array}$ \\
\hline \multirow[t]{2}{*}{ Pair 1} & Pre Test & 21.00 & 22 & 1.902 & .406 \\
\hline & Post Test & 23.00 & 22 & 1.718 & .366 \\
\hline
\end{tabular}

The average value of pretest is lower than posttest, meaning that descriptively there is a difference in the average learning outcomes between pretest and posttest. This means that learning outcomes have increased.

Table 5. Paired Samples Correlations

\begin{tabular}{ccccc}
\hline & & N & Correlation & Sig. \\
\hline Pair 1 & Pre Test \& Post Test & 22 & .845 & .000 \\
\hline
\end{tabular}

The correlation table shows the correlation coefficient (correlation) of 0.845 with a significant value (Sig.) of 0.000 . Because of the value of Sig. $<0.05$ probability, it can be concluded that there is a relationship between pretest and posttest.

Table 6. Paired Samples Test

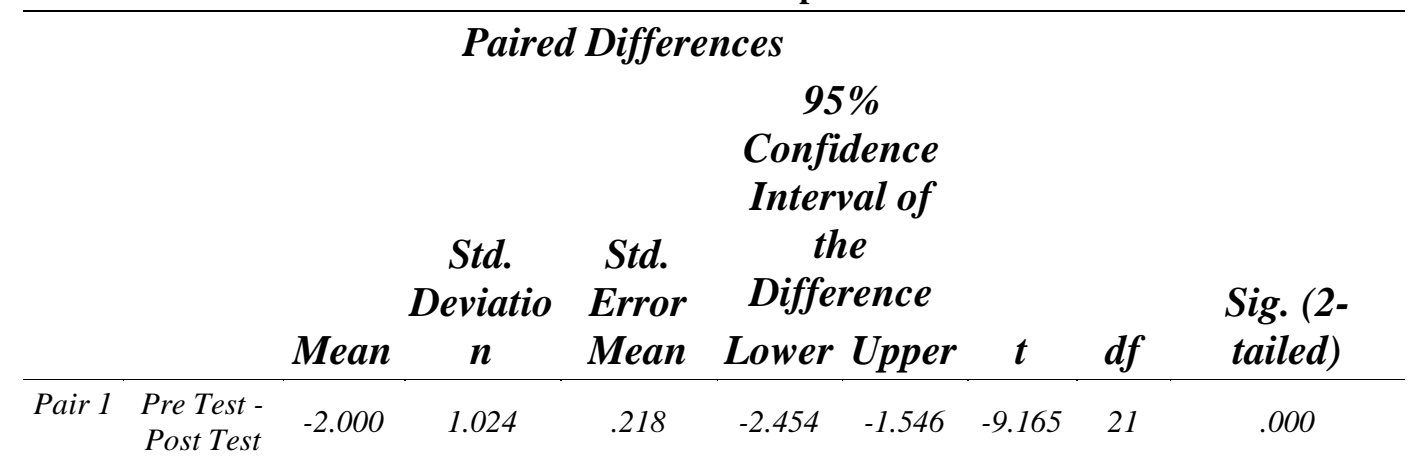

The table paired sample test shows the value of Sig. (2-tailed) $<0.05$, then $\mathrm{H} 0$ is rejected, and $\mathrm{H} 1$ is accepted. So it can be concluded that there is an average difference between the pretest and posttest learning outcomes. Thus it can be concluded that there is an increase and learning outcomes after treatment.

\section{DISCUSSION}

\subsection{Student Activities}

The results of observing student activities in the trials and research carried out are known that students can; 1) Formulate the problem clearly and be directed to find answers. 2) Analyze weaknesses or limitations in data collection. 3) Formulate hypotheses based on knowledge possessed. 4) Write correct conclusions and are supported by data. 5) Evaluate conclusions made accompanied by logical reasons. 6) Provide possible alternative solutions to solve the problem. 7) Accept or reject opinions, ideas, or decisions accompanied by clear and logical reasons. These rights have increased at each meeting.

\subsection{Student Learning Outcomes}

The assessment of students was carried out twice, namely pretest and posttest. This is done to determine the aspects of students' initial knowledge in learning and knowledge of student learning outcomes after participating in integrative learning models.

The application of the results of the development of an integrative model can improve the completeness of learning objectives from the aspect of knowledge. Based on the results of student work on the knowledge aspect in the posttest, all achieved completeness. The increase shown by the analysis results using the paired sample test showed an average difference in learning outcomes between the pretest and posttest, which means that learning outcomes have increased. Thus 
it can be concluded that there is an increase in learning outcomes after treatment. However, students still need continuous practice so that they are accustomed to using critical thinking skills in solving lecture problems and the learning outcomes achieved are more optimal.

\section{3 Student Response}

Based on the analysis of student responses to the development of the device, most of the students responded positively to interest, novelty, and ease of understanding the learning components. The response shows that students can well accept all learning components, including learning activities, Student Activity Sheets, learning materials (Teaching Materials), and how the lecturers teach. According to (Arends, 2012) if the problems given to students make them feel challenged, new and interesting, then in the learning process, students will exert all efforts to solve the problem both individually and in groups and can trigger intrinsic motivation.

Responses of student interest in the learning component were 1 student (94.57\%), 5 students (95.65\%), 13 students (96.74\%) and 3 students (97.83). Thus the average data on student responses to the integrative learning model is 88 with a percentage of $96.54 \%$ with the assessment criteria included in the very good category. This shows that students feel clear with the lecturer's explanation during learning, and students are very interested if learning using an integrative model is taught for the next subject.

\section{CONCLUSION}

The implementation of the Introduction to Education course in the Indonesian Language and Literature Education Study Program, Faculty of Teacher Training and Education, Tomakaka University, Mamuju, refers to the Semester Learning Plan (RPS) and Lecture Program Unit (SAP) compiled by the lecturer. The learning model applied so far is still conventional. Therefore, innovation is carried out through this research by developing an integrative model of Manakarra values.

The results of the analysis and discussion of research indicate that the student's response to the integrative model of Manakarra's values is positive. This is based on students' interest in learning by using the learning model that has been developed. In addition, students get a good understanding of learning with this model. The design of the Manakarra valuebased learning model begins with the validity of learning tools in the form of Model Books, Teaching Materials, Semester Learning Plans (RPS), Student Activity Sheets and Learning Outcomes Test Instruments. The instrument received an assessment from an expert validator with a very feasible category for implementation. As the trials conducted in teaching Introduction to Education courses at the Indonesian Language and Literature Education Study Program, the Faculty of Teacher Training and Education, Tomakaka University, Mamuju, received a good response from students.

\section{REFERENCES}

Abbot, P., Tyler, M., \& Wallace, C. (2005). An Introduction to Sociology. Routledge.

Aqib, Z. (2014). MODEL-MODEL, MEDIA dan STRATEGI PEMBELAJARAN KONTEKSTUAL(INOVATIF). YRAMA WIDYA.

Arends, R. I. (2012). Learning to Teach (9th Ed). McGraw-Hill.

Budiningsih, A. (2005). Belajar dan Pembelajaran. Rineka Cipta.

Gray, R., \& Wheatley, K. (1991). How to avoid bias when comparing bone marrow transplantation with chemotherapy. Bone Marrow Transplantation, 7 Suppl 3. https://pubmed.ncbi.nlm.nih.gov/1855097/

Hudoyo, H. (1990). Strategi mengajar belajar matematika. IKIP Malang.

Idham \& Shaprillah. (2013). Malaqbiq Mandar Identity. Arti Bumi Intaran.

Kondziolka, D., Dempsey, P. K., Lunsford, L. D., Kestle, J. R., Dolan, E. J., Kanal, E., \& Tasker, R. R. (1992). A comparison between magnetic resonance imaging and computed tomography for stereotactic coordinate determination. Neurosurgery, 30(3). https://pubmed.ncbi.nlm.nih.gov/1620305/

Sedyawati, E. (2012). Budaya Indonesia (5th Ed.). Rajawali Pers.

Suciati, \& Irawan, P. (2001). Teori Belajar dan Motivasi. PAU-PPAI Universitas Terbuka.

Sugiyono. (2010). Metode Penelitian Kuantitatif Kualitatif dan R\&D. Alfabeta.

Thahir, I. Abd. R. (2006). Overview of the Mamuju Indigenous History. 